\title{
NON-CRYSTALLINE COPPER OXIDE HIGHLY DISPERSED ON MESOPOROUS ALUMINA: SYNTHESIS, CHARACTERIZATION AND CATALYTIC ACTIVITY IN GLYCEROL CONVERSION TO ACETOL
}

\author{
Tiago Pinheiro Braga ${ }^{\mathrm{a}, *}$, Nadine Essayem ${ }^{\mathrm{b}}$ and Antoninho Valentini ${ }^{\mathrm{c}}$ \\ a'Laboratório de Peneiras Moleculares, Universidade Federal do Rio Grande do Norte, 59078-970 Natal - RN, Brasil \\ 'Institut de Recherches Sur La Catalyse et L'Environnement, 2 Av. A. Einstein, 69626 Villeurbanne Cedex, France \\ 'Departamento de Química Analítica e Físico-Química, Universidade Federal do Ceará, Campus do Pici, 60455-970 Fortaleza - \\ CE, Brasil
}

Recebido em 23/10/2015; aceito em 17/02/2016; publicado na web em 29/04/2016

\begin{abstract}
Polymeric precursor method and wet impregnation route were applied to synthesize copper and aluminium-based catalysts in order to obtain a material with interesting properties in catalytic reactions. The changes in the structural, morphological and textural properties due to the choice of preparation method were characterized by different techniques, such as XRD, $\mathrm{N}_{2}$ physisorption isotherms and SEM. The XRD results of the solids present the formation of $\gamma-\mathrm{Al}_{2} \mathrm{O}_{3}$ or $\mathrm{CuO}$ and $\beta-\mathrm{Al}(\mathrm{OH})_{3}$, depending on the preparation method. The average crystallite diameters of the alumina were estimated by the Scherrer's formula with a particle size of $5.2 \mathrm{~nm}$. $\mathrm{N}_{2}$ physisorption isotherms analysis shows that the alumina is a mesoporous material with a high specific surface area. An excessive increase in surface area was observed after $\mathrm{Cu}^{2+}$ insertion by wet impregnation from $\beta-\mathrm{Al}(\mathrm{OH})_{3}$ support, which is explained by the redissolution and recrystallization of bayerite to $\gamma-\mathrm{Al}_{2} \mathrm{O}_{3}$ during the impregnation of $\mathrm{Cu}^{2+}$ and recalcination process, respectively. The SEM images confirmed this phenomenon. Catalytic tests explain that the combination of the two methods improves the activity, selectivity and the stability in the conversion of glycerol to acetol. The results indicate that the way of catalyst preparation affects its structural, textural and morphological properties and consequently the catalytic performance.
\end{abstract}

Keywords: copper oxide; alumina; bayerite; glycerol; acetol.

\section{INTRODUCTION}

The increasing production of biodiesel has resulted in a price decline of crude glycerol, consequently the utilization of glycerol to produce valuable chemicals, such as 1-hydroxypropan-2-one (acetol) and propylene glycol (1,2-propanediol), becomes an interesting research topic. ${ }^{1,2}$ The opportunity exists to market acetol as reduced dyes, food industry (give aroma to foods), flavor compounds in heated milk, skin tanning agent, as well as to produce chemicals such as propylene glycol, propionaldehyde, acetone and furan derivatives. ${ }^{3-5}$ Furthermore, acetol is an interesting molecule from astrophysical perspective. , $^{6,7}$

The conversion of glycerol to acetol may be conducted via dehydration and/or dehydrogenation reaction. ${ }^{1,8}$ Sato et al. ${ }^{1}$ reported that, for the copper oxide-based catalysts, the major product of glycerol conversion is acetol. The glycerol dehydration proceeds through the formation of $\mathrm{Cu}$-alkoxide species followed by hydrogen abstraction from the secondary hydroxyl groups. ${ }^{8-10}$ The alkoxide generated from glycerol may release an $\mathrm{OH}$ radical from the primary $\mathrm{OH}$ groups to produce acetol. However, copper-alkoxide species may also be produced by interaction with primary hydroxyl groups from glycerol to generate acetol. ${ }^{8-11}$ On the other hand, the control of surface acid-base character of support for the copper based-catalysts plays an important role during the glycerol conversion to acetol..$^{5,8-11}$

The most important disadvantage to the gas-phase transformation of glycerol to acetol, mainly on acid catalysts, is the deactivation due to extensive coke deposition on the catalyst surface, as well as the sintering process. ${ }^{8,12}$ Therefore, the development of a catalyst resistant to deactivation by coke and the sample sintering during the conversion of glycerol to acetol in gas phase is one of the most interesting research challenges.

*e-mail: tiagoquimicaufrn@gmail.com
Spinels, with the general formula $\mathrm{M}^{\mathrm{II}} \mathrm{M}_{2}^{\mathrm{III}} \mathrm{O}_{4}$, are an important class of oxide materials which have many potential catalytic applications. ${ }^{13-18}$ Aluminium based spinels constitute an important group of advanced materials with wide variety of technological applications. ${ }^{13-19}$ Copper(II) aluminate, $\mathrm{CuAl}_{2} \mathrm{O}_{4}$, which is known to be an inverse spinel, contains a $\mathrm{d}^{9}$ metal ion and possesses interesting catalytic properties. ${ }^{20,21} \mathrm{CuAl}_{2} \mathrm{O}_{4}$ is formed by solid-solid interaction between $\mathrm{CuO}$ and $\mathrm{Al}_{2} \mathrm{O}_{3}$. Detailed studies on the structure phase of defective copper-alumina (copper-modified alumina) are rarely reported. Furthermore, it was observed that the aluminate spinel may effectively inhibit the coke formation and the thermal sintering. ${ }^{22}$ Copper aluminate-like structure (copper-modified alumina) is rarely studied in the glycerol conversion to byproducts, ${ }^{23}$ remaining as a largely unexplored research topic.

Braga et al. ${ }^{24}$ recently showed the synthesis and characterization of different acid supports, $\mathrm{Cu}-\mathrm{M}_{x} \mathrm{O}_{y} / \mathrm{Al}_{2} \mathrm{O}_{3}(\mathrm{M}=\mathrm{Fe}, \mathrm{Zn}, \mathrm{W}$ or $\mathrm{Sb})$, combined with copper oxide using similar synthetic route and applied in the glycerol conversion to acetol. This study presents the acidity effect of the support and the influence of copper oxide structure on the glycerol catalytic activity. However, the catalytic performance was not presented for the pure aluminium and $\mathrm{Cu}-\mathrm{Al}$ oxide. Also, the significant increase in surface area of the support after the copper impregnation was not well explained. Thus, further research is needed in order to clarify these points.

Thus, the present study shows the successful method for preparing non-crystalline copper oxide dispersed on mesoporous alumina with a high surface area and the same catalysts are tested in the conversion of glycerol to acetol in gas phase. Despite the importance of transition aluminas for technological and industrial applications, several aspects concerning the chemistry of aluminas, especially combined with other metals such as copper, are still not clear. In this paper, it is presented an unusual change in structural, morphological and textural properties of the alumina with highly dispersed copper oxide prepared using a 
combination of two methods (polymeric precursor method and wet impregnation route).

\section{EXPERIMENTAL}

\section{Catalyst preparation}

This method is based on the chelation of metallic cations $\left(\mathrm{Cu}^{2+}\right.$ and $\mathrm{Al}^{3+}$ ) by citric acid in a water solution followed by a polyesterification of the remaining carboxylic acid function with ethylene glycol. Aluminum nitrate nonahydrate $\left\{\mathrm{Al}\left(\mathrm{NO}_{3}\right)_{3} \cdot 9 \mathrm{H}_{2} \mathrm{O}\right\}$, copper nitrate trihydrate $\left\{\mathrm{Cu}\left(\mathrm{NO}_{3}\right)_{2} \cdot 3 \mathrm{H}_{2} \mathrm{O}\right\}$, citric acid monohydrate (CA) $\left\{\mathrm{C}_{6} \mathrm{H}_{8} \mathrm{O}_{7} \cdot \mathrm{H}_{2} \mathrm{O}\right\}$, and ethylene glycol (EG) $\left\{\mathrm{C}_{2} \mathrm{H}_{6} \mathrm{O}_{2}\right\}$ were used as starting chemicals. A CA/metal ratio of 2:1 (mol) was used for all the samples. The metal amount is the sum of $\mathrm{Cu}$ and $\mathrm{Al}$. The mass ratio of CA/EG was kept at 2:3. The sample was labeled as $\mathrm{XCuAl}$, with $\mathrm{X}$ denoting the $\mathrm{Cu} / \mathrm{Al}$ weight ratio. The sample containing only aluminum oxide was denominated $\mathrm{Al}$.

For the synthesis process of the $3 \mathrm{CuAl}$ sample, where 3 is the $\mathrm{Cu} / \mathrm{Al}$ weight ratio, $\mathrm{Cu}$ and $\mathrm{Al}$ salts, respectively, was dissolved in distilled water at room temperature. CA was dissolved in ethanol at $50{ }^{\circ} \mathrm{C}$. Later, the aqueous solution was added to the CA-ethanol solution and stirred during $60 \mathrm{~min}$ at $50{ }^{\circ} \mathrm{C}$. Subsequently, the EG was added, and the mixture was stirred for $4 \mathrm{~h}$ at $100{ }^{\circ} \mathrm{C}$ until it became a viscous resin. The resin was treated at $250{ }^{\circ} \mathrm{C}$ for $1 \mathrm{~h}$ under air atmosphere. The resulting precursor composite was ground and treated at $500{ }^{\circ} \mathrm{C}$ under air flow for $2 \mathrm{~h}$. The same conditions were used to prepare $\mathrm{Al}$ sample.

\section{Wet impregnation method}

$\mathrm{Cu}$ dispersed on $\gamma-\mathrm{Al}_{2} \mathrm{O}_{3}$ catalyst was prepared by wet impregnation from the aluminium oxide support synthesized by polymeric precursor method (Al sample, as described above) with an aqueous solutions of copper nitrate trihydrate $\left\{\mathrm{Cu}\left(\mathrm{NO}_{3}\right)_{2} \cdot 3 \mathrm{H}_{2} \mathrm{O}\right\}$ in a rotary evaporator. After impregnation, the sample was calcined at $500{ }^{\circ} \mathrm{C}$ in muffle furnace for $1 \mathrm{~h}\left(5^{\circ} \mathrm{C} \mathrm{min}^{-1}\right)$. The sample was denominated $\mathrm{XCuAlY}$, with $\mathrm{X}$ representing the $\mathrm{Cu} / \mathrm{Al}$ weight and $\mathrm{Y}$ indicating the calcinations temperature.

\section{Catalyst characterization}

The $\mathrm{Cu}$ content was determined by ICP after dissolution by acid attack using the line of emission of $\mathrm{Cu}$. The crystal structure of the metal oxides was characterized by X-ray diffraction analysis (XRD), with $\mathrm{Cu} \mathrm{K} \alpha$ irradiation source $(\lambda=1.540 \AA$, $40 \mathrm{kV}$ and $40 \mathrm{~mA})$. Specific surface area (BET) and pore volume of the catalysts were determined by $\mathrm{N}_{2}$ adsorption/desorption isotherms, at liquid nitrogen temperature. The catalyst samples $(80 \mathrm{mg})$ were vacuum treated at $200{ }^{\circ} \mathrm{C}$ for $1 \mathrm{~h}$. The morphology of the catalysts was examined by the use of scanning electron microscopy (SEM) at $20 \mathrm{kV}$.

\section{Catalytic tests}

Catalytic tests were carried out in a fixed bed microreactor, using $200 \mathrm{mg}$ of sample. All fresh catalysts were firstly reduced in $\mathrm{H}_{2}\left(25 \mathrm{~mL} \mathrm{~min}^{-1}\right)$ at $250{ }^{\circ} \mathrm{C}$ for $1 \mathrm{~h}$. After the temperature of the catalyst bed had been maintained at $250{ }^{\circ} \mathrm{C}$ in hydrogen flow for 1 $\mathrm{h}$, an aqueous solution of glycerol at $10 \mathrm{wt}$ \% was fed through the reactor top by a micro-pump at the feed rate of $1.8 \mathrm{~cm}^{3} \mathrm{~h}^{-1}$, which corresponded to $0.06 \mathrm{~mol}$ of glycerol per hour, combined with a gas (hydrogen) flow rate of $25 \mathrm{~mL} \mathrm{~min}{ }^{-1}$. The liquid products were collected in an ice-water-salt trap $\left(-6^{\circ} \mathrm{C}\right)$ in order to be analyzed every hour on a gas chromatograph with a mass spectrometer and a gas chromatograph connected to a hydrogen flame ionization detector (FID-GC), using a capillary column purchased from Varian, CP 9048 (length: $30 \mathrm{~m}$, diameter: $0.32 \mathrm{~mm}$, thickness of the stationary phase: $0.1 \mathrm{~mm}$ ).

\section{RESULTS AND DISCUSSION}

\section{X-Ray diffraction}

The X-ray diffraction patterns are presented in Figure 1. The crystalline phases were identified in comparison with ICDD files. The Al sample is poorly crystalline material and present X-ray patterns of an amorphous solid. However, after multiplying the signal intensity by 4 , it is possible to notice some weak broader peaks $(18.6,20.4$, 40.6 and 53.3 degrees) related to $\beta-\mathrm{Al}(\mathrm{OH})_{3}$ phase formation (JCPDS 00-008-0096). On the other hand, the sample $3 \mathrm{CuAl}$ clearly pointed out the formation of a copper oxide phase (CuO, JCPDS 04-006-2679) as well as the $\beta-\mathrm{Al}(\mathrm{OH})_{3}$ phase (JCPDS 00-008-0096).

The samples prepared by wet impregnation $(3 \mathrm{CuAl} 500)$ presented a XRD profile which points to the formation of a material with poorly crystalline organization. In spite of that, the profile suggests the aluminium oxide formation $\left(\gamma-\mathrm{Al}_{2} \mathrm{O}_{3}\right.$, JCPDS 00-0021414), however, it was not observed crystalline phase of copper oxide, possibly indicating the formation of highly dispersed copper species in alumina matrix.

From this results, one can notice that the samples synthesized by wet impregnation method $(3 \mathrm{CuAl} 500)$ stimulate the formation of aluminium oxide phase with copper oxide highly dispersed compared to the $3 \mathrm{CuAl}$ catalyst prepared using only the polymeric precursor method, which show the presence of $\beta-\mathrm{Al}(\mathrm{OH})_{3}$ and $\mathrm{CuO}$ with defined crystallinity.

High dispersed copper oxide phase is probably formed as a result of the thermal solid-state reaction according to the following reaction: $\mathrm{CuO}+\mathrm{Al}_{2} \mathrm{O}_{3} \rightarrow \mathrm{CuAl}_{\mathrm{x}} \mathrm{O}_{\mathrm{y}},{ }^{25,26}$ which indicates that $\mathrm{CuO}$ diffused onto the surface of defective spinel-type- $\gamma-\mathrm{Al}_{2} \mathrm{O}_{3} .{ }^{27}$ This suggests that $\mathrm{CuO}-\mathrm{Al}_{2} \mathrm{O}_{3}$ interaction was probably promoted in the samples synthesized by wet impregnation method and it was not possible in the catalyst prepared using only the polymeric precursor method, which presented the formation of copper oxide and hydrated aluminum oxide separately. This phase was not well characterized in any previous literature related to $\mathrm{Al}_{2} \mathrm{O}_{3}$ and $\mathrm{Al}-\mathrm{Cu}-\mathrm{O}$ system. ${ }^{28,29}$ Therefore, in this paper, as previously mentioned, ${ }^{30}$ the transition phase was designated $\mathrm{Cu}$-modified $\gamma-\mathrm{Al}_{2} \mathrm{O}_{3}$, which the copper is highly dispersed on $\gamma-\mathrm{Al}_{2} \mathrm{O}_{3}$, whereas it is not observed defined XRD peaks concerning the crystalline phase of copper oxide. However, for the $3 \mathrm{CuAl}$ sample, the isolated $\mathrm{CuO}$ phase is not extremely dispersed on the $\beta-\mathrm{Al}(\mathrm{OH})_{3}$ support, since intense and defined XRD peaks related to copper oxide were observed. Some studies in the literature report that addition of metal ions $\left(\mathrm{M}^{\mathrm{n}+}\right)$ on the support with appropriate $\mathrm{pH}$ during the impregnation step catalyzes the transformation of the alumina phase, which can justify the recrystallization of $\beta-\mathrm{Al}(\mathrm{OH})_{3}{ }^{31-33}$

The average crystallite diameter was estimated from the diffraction data using the Scherrer's formula (Table 1). The average crystallite sizes for alumina particles was $5.2 \mathrm{~nm}$ for the sample $3 \mathrm{CuAl} 500$. However, the average crystallite size for $3 \mathrm{CuAl}$ catalyst was $24.8 \mathrm{~nm}$. The reflections are quite broad for the alumina peaks, indicating the formation of fine nanostructure. Thus, the wet impregnation method from the $\beta-\mathrm{Al}(\mathrm{OH})_{3}$ synthesized by polymeric precursor method is a successful route for preparing nanometer-sized samples containing alumina combined with a non-crystalline structure of copper oxide (highly dispersed on alumina matrix). 


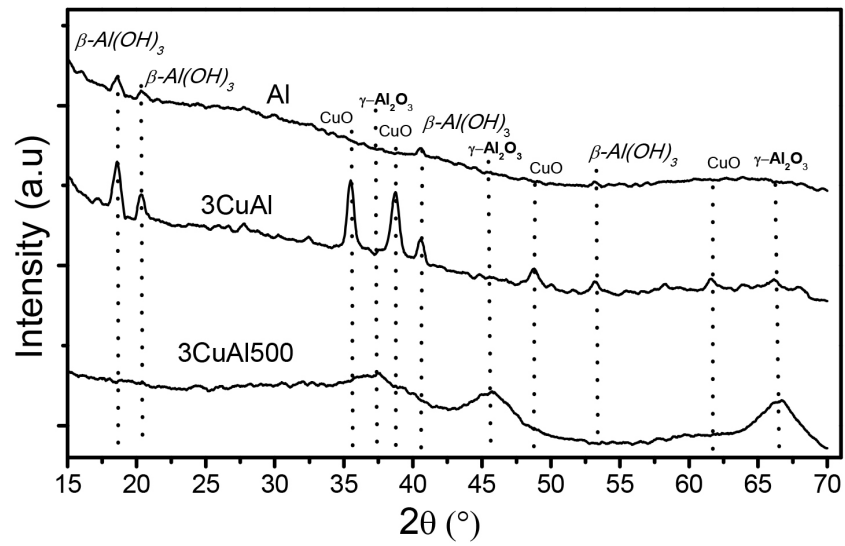

Figure 1. X-Ray diffraction profile of the samples after the calcination. The values were multiplied by 4 for the Al sample. Al: pure alumina by the polymeric precursor method, 3CuAl: copper-aluminium oxide by the polymeric precursor method and 3CuAl500: copper-aluminium oxide by wet impregnation

Table 1. Average crystallite sizes of the solids after calcination process

\begin{tabular}{cccc}
\hline \multirow{2}{*}{ Samples } & \multicolumn{3}{c}{ crystallite sizes $(\mathrm{nm})$} \\
\cline { 2 - 4 } & $\beta-\mathrm{Al}(\mathrm{OH})_{3}$ & $\mathrm{CuO}$ & $\gamma-\mathrm{Al}_{2} \mathrm{O}_{3}$ \\
\hline $3 \mathrm{CuAl}$ & 24.2 & 24.8 & - \\
$3 \mathrm{CuAl} 500$ & - & 4.9 & 5.2 \\
\hline
\end{tabular}

\section{Specific surface area measurements}

The nitrogen adsorption/desorption isotherms of the calcined sample prepared from the two method described above are shown in Figure 2 and the textural properties are summarized in Table 2.

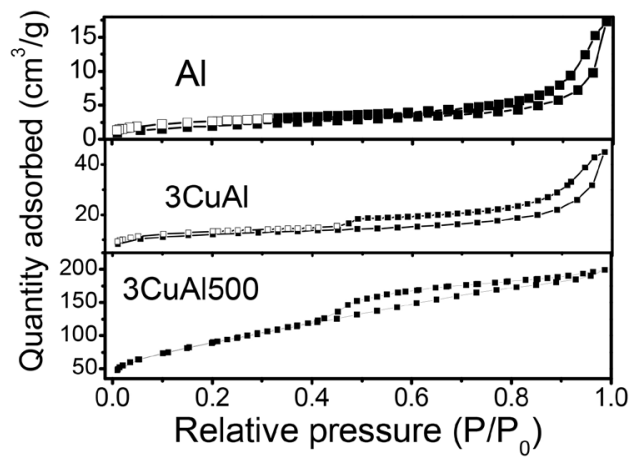

Figure 2. $\mathrm{N}_{2}$ adsorption/desorption isotherms of the catalysts

The samples $\mathrm{Al}$ and $3 \mathrm{CuAl}$ prepared using only the polymeric precursor method showed analogous isotherm profiles characteristic of mesoporous materials (type II isotherms), which are obtained with aggregates of plate-like particles and therefore possess non-rigid, slit shaped pores. On the other hand, the samples synthesized using wet impregnation method from the $\beta-\mathrm{Al}(\mathrm{OH})_{3}$ synthesized by polymeric precursor route exhibit a typical type IV curve with $\mathrm{H} 2$ hysteresis loops, characteristic of mesoporous materials according to the IUPAC classification. All isotherms display a sharp step typical of capillary condensation of nitrogen within mesopores, where the $\mathrm{P} / \mathrm{P}_{0}$ position of the inflection point is correlated to the diameter of the mesopores.

Table 2 lists the surface area $\left(\mathrm{S}_{\mathrm{BET}}\right)$, total pore volume $(\mathrm{Vp})$ and average pore diameter $(\mathrm{Dp})$ of solids. It is interesting to note that the specific surface area and the total pore volume of the Al sample prepared by polymeric precursor method increase after the addition of copper by wet impregnation route. For example, the specific surface area for the $\mathrm{Al}$ material compared to the $3 \mathrm{CuAl} 500$ catalyst increases from 7 to $328 \mathrm{~m}^{2} \mathrm{~g}^{-1}$ and the specific pore volume of the solid also increases from 0.03 to $0.3 \mathrm{~cm}^{3} \mathrm{~g}^{-1}$. Contrary, the sample $3 \mathrm{CuAl}\left(41 \mathrm{~m}^{2} \mathrm{~g}^{-1}\right)$ containing mixed copper-aluminum oxide prepared using only the polymeric precursor method indicated that the specific surface area is not extremely different compared to the $\mathrm{Al}$ catalyst $\left(7 \mathrm{~m}^{2} \mathrm{~g}^{-1}\right)$ synthesized in the same way.

Table 2. Properties of the samples acquired by $\mathrm{N}_{2}$ adsorption/desorption isotherms

\begin{tabular}{cccc}
\hline Samples & $\mathrm{S}_{\mathrm{BET}}\left(\mathrm{m}^{2} / \mathrm{g}\right)$ & $\mathrm{Vp}\left(\mathrm{cm}^{3} / \mathrm{g}\right)$ & $\mathrm{Dp}(\mathrm{nm})$ \\
\hline $\mathrm{Al}$ & 7 & 0.03 & 15.3 \\
3CuAl & 41 & 0.06 & 10.6 \\
3CuA1500 & 328 & 0.31 & 3.9 \\
\hline
\end{tabular}

Such textural effects in the porosity of the solids may be related to the information evidenced in the XRD patterns (Figure 1). That is manifested by phase segregation, chemical interactions and polymorphous transformations of the bayerite support (transition of $\beta-\mathrm{Al}(\mathrm{OH})_{3}$ to $\left.\gamma-\mathrm{Al}_{2} \mathrm{O}_{3}\right)$ during impregnation process. However, the induced increase in the $\mathrm{S}_{\mathrm{BET}}$ and $\mathrm{Vp}$ of the sample prepared by wet impregnation may be also attributed to the creation of pores produced from liberation of nitrogen oxides gas during the thermal decomposition of $\mathrm{Cu}\left(\mathrm{NO}_{3}\right)_{2}$. Thus, the way of catalyst preparation influences its structure and texture, as observed in Figures 1 and 2, as well as in Tables 1 and 2 .

\section{Scanning electron microscopy (SEM)}

The morphological features of the sample prepared by two different methods were observed by scanning electron microscopy (Figure 3). The catalysts synthesized using only the polymeric precursor method present a sponge-like morphology, which reveals a high level of porosity. The sponge-like morphology is the result of a thermal decomposition of the organic compounds (CA and EG) and inorganic precursors (nitrates) during the calcination process, which opens channels through the oxide matrix. There are practically no differences between $\mathrm{Al}$ and $3 \mathrm{CuAl}$ images, as can be seen in Figures 3-a and 3-b.

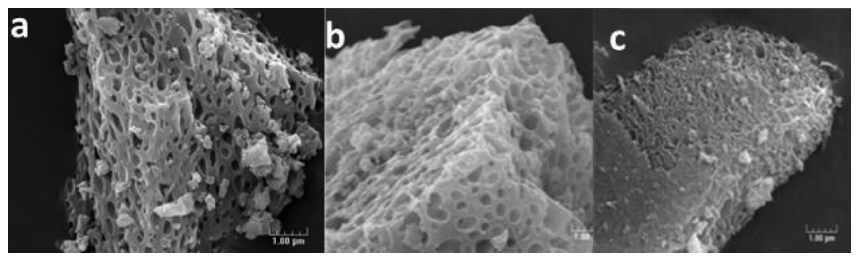

Figure 3. SEM images after the calcinations: $\boldsymbol{a})$ Al sample; b) 3CuAl catalyst and c) 3 CuAl500 solid

On the other hand, the sample $3 \mathrm{CuAl} 500$ synthesized using wet impregnation route from the $\beta-\mathrm{Al}(\mathrm{OH})_{3}$ prepared by polymeric precursor method shows a thin leaf-like morphology (Figure 3-c), which is probably related to the formation of $\gamma-\mathrm{Al}_{2} \mathrm{O}_{3}$ phase, as seen in the XRD pattern (Figure 1). Consequently, the choice of catalyst preparation conditions also influences on the morphology of the catalysts.

These results suggest that probably during the wet impregnation of copper nitrate occurs the redissolution of aluminum hydroxide $\left(\beta-\mathrm{Al}(\mathrm{OH})_{3}\right)$, leading to the formation of $\gamma-\mathrm{Al}_{2} \mathrm{O}_{3}$ after calcination at $500{ }^{\circ} \mathrm{C}$. The redissolution followed by recrystallization may explain 
the high dispersion obtained for copper oxide, results indicated by $\mathrm{X}$-ray diffraction and the significant increase in surface area and pore volume, as shown in Table 2. It is important to emphasize that the solubility of $\beta-\mathrm{Al}(\mathrm{OH})_{3}$ in water depends on $\mathrm{pH}$, and the redissolution of the support $\beta-\mathrm{Al}(\mathrm{OH})_{3}$ can take place in $\mathrm{pH}=5$ ( $\mathrm{pH}$ of the copper nitrate solution). ${ }^{22}$

It was carried out additional experiments and characterizations in order to confirm that the way to prepare the catalysts leads to a structural transformation and may also lead to a change in the texture of the catalyst (see Figure 3 and Table 2).

Firstly, the sample Al, which showed the formation of $\beta-\mathrm{Al}(\mathrm{OH})_{3}$, was recalcined at $800{ }^{\circ} \mathrm{C}$ under air atmosphere to promote the formation of unhydrated aluminum oxide (A1800). Subsequently, after recalcination at $800{ }^{\circ} \mathrm{C}$, the solid containing aluminum oxide was subjected to the process of wet impregnation for the addition of copper and, finally, the material was calcined again at $500{ }^{\circ} \mathrm{C}$, similar to the route for the preparation of sample $3 \mathrm{CuAl} 500$. The sample was designated $3 \mathrm{CuAl} 800$, where 3 represents the $\mathrm{Cu} / \mathrm{Al}$ weight ratio and 800 symbolizes the recalcination temperature of the A1800 support.

It was performed XRD analysis for the two new samples, Al800 and $3 \mathrm{CuAl} 800$, to confirm the crystalline phases obtained in the additional experiments (Figure 4). These two materials were compared with the solids $\mathrm{Al}$ and $3 \mathrm{CuAl} 500$ described previously (Figure 1) to verify the influence of the synthesis process on the obtained structure.

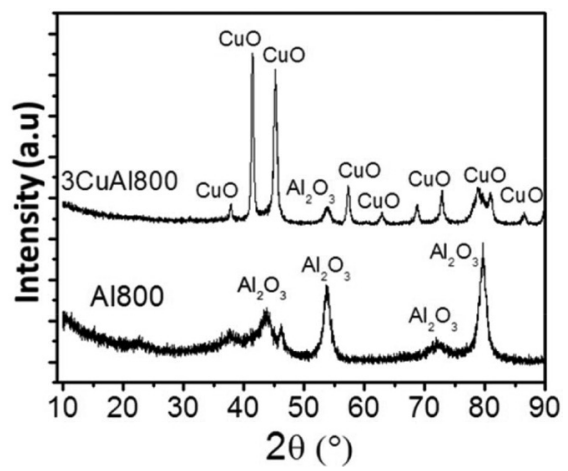

Figure 4. X-Ray diffraction results of the samples Al800 and $3 C \mathrm{Cu} 1800$

From the Figure 4, it was noticed that the sample $\mathrm{Al}$ after recalcination at $800{ }^{\circ} \mathrm{C}$ exhibited a phase transformation of $\beta-\mathrm{Al}(\mathrm{OH})_{3}$ to gamma-alumina $\left(\gamma-\mathrm{Al}_{2} \mathrm{O}_{3}\right.$, JCPDS 00-04-0858). Figure 4 also shows that after addition of copper by wet impregnation from $\gamma-\mathrm{Al}_{2} \mathrm{O}_{3}$ support (A1800), it was observed the formation of copper oxide $(\mathrm{CuO}$, JCPDS 00-003-0867), crystalline phase, besides the gamma-alumina, unlike the catalyst $3 \mathrm{CuAl} 500$ which presented the $\gamma-\mathrm{Al}_{2} \mathrm{O}_{3}$ structure with copper oxide (non-crystalline phase) highly dispersed on the support (Figure 1)

Therefore, it is not possible to identify by XRD the formation of copper oxide (isolated $\mathrm{CuO}$ phase) for the $3 \mathrm{CuAl} 500$ material compared to the solid $3 \mathrm{CuAl} 800$. However, in both cases, the calcination temperature employed after copper impregnation of $\mathrm{Cu}^{2+}$ was $500{ }^{\circ} \mathrm{C}$, modifying only the crystalline phase of the support $\left(\left[\beta-\mathrm{Al}(\mathrm{OH})_{3}\right]\right.$ for the $3 \mathrm{CuAl} 500$ and $\gamma-\mathrm{Al}_{2} \mathrm{O}_{3}$ for the $3 \mathrm{CuAl} 800$ ). Thus, the physicochemical properties of the materials are favored when the impregnation process is carried out using the $\beta-\mathrm{Al}(\mathrm{OH})_{3}$ support, however, it is not observed when the impregnation has been made with $\gamma-\mathrm{Al}_{2} \mathrm{O}_{3}$ support.

Furthermore, it was also noted that when the copper impregnation has been made from the $\beta-\mathrm{Al}(\mathrm{OH})_{3}$, the surface area increases by a factor of approximately forty times (Table 2 ). In order to confirm that the redissolution and recrystallization of $\beta-\mathrm{Al}(\mathrm{OH})_{3}$ are responsible for the textural changes, the samples $\mathrm{Al} 800$ and $3 \mathrm{CuA} 1800$ were also analyzed by nitrogen adsorption/desorption isotherms. The result indicates that the surface area values of the solid Al800 $\left(8 \mathrm{~m}^{2} \mathrm{~g}^{-1}\right)$ was practically the same compared to the support $\mathrm{Al}\left(7 \mathrm{~m}^{2} \mathrm{~g}^{-1}\right)$. Thus, the result confirms that the transformation of hydrated alumina $\left(\beta-\mathrm{Al}(\mathrm{OH})_{3}\right.$ to $\left.\gamma-\mathrm{Al}_{2} \mathrm{O}_{3}\right)$ using only the polymeric precursor route due to the increase of the calcination temperature without impregnation of $\mathrm{Cu}^{2+}$ (from 500 to $800{ }^{\circ} \mathrm{C}$ ) does not provide an increase in the surface area. Hence, the wet impregnation method is essential for the observed changes in the textural properties due to redissolution and recrystallization of aluminum hydroxide (bayerite).

In addition, the catalyst $3 \mathrm{CuAl} 800$ exhibited a specific surface area of $92 \mathrm{~m}^{2} \mathrm{~g}^{-1}$. Therefore, this result indicates that the impregnation of copper nitrate from the support $\gamma-\mathrm{Al}_{2} \mathrm{O}_{3}$ does not lead to a large increase in the surface area compared to the solid $3 \mathrm{CuAl} 500$ $\left(328 \mathrm{~m}^{2} \mathrm{~g}^{-1}\right)$, which the impregnation of copper nitrate was carried out from the support $\beta-\mathrm{Al}(\mathrm{OH})_{3}$.

The persistence of phase $\beta-\mathrm{Al}(\mathrm{OH})_{3}$ even after the first calcination at $500{ }^{\circ} \mathrm{C}$ for $\mathrm{Al}$ and $3 \mathrm{CuAl}$ samples (Figure 1) may be attributed to the synthesis method employed. The synthetic route chosen uses organic matter (citric acid and ethylene glycol), which undergoes thermal decomposition or elimination. Moreover, Figure 3 shows in microscopic scale that the thermal decomposition and/or elimination process generate pores and the organic material acts as a physical barrier preventing the sintering process of the inorganic fraction during the calcination, justifying the maintenance of the $\beta-\mathrm{Al}(\mathrm{OH})_{3}$ structure for the $\mathrm{Al}$ and $3 \mathrm{CuAl}$ samples.

On the other hand, in the recrystallization process at $500{ }^{\circ} \mathrm{C}$ (second calcination, after impregnation of $\mathrm{Cu}^{2+}$ ), it was observed the phase $\gamma-\mathrm{Al}_{2} \mathrm{O}_{3}$ and the absence of phase $\beta-\mathrm{Al}(\mathrm{OH})_{3}$ due to the fact that the organic material which acts as a physical barrier was completely removed. Thus, in the second calcination process, it was noticed the normal sequence of crystallization for the transition aluminas.

It is known that the pore diameters observed by SEM cannot be compared with the pore diameters obtained from nitrogen adsorption/desorption isotherms. However, Figure 3 suggests that the wet impregnation process of copper nitrate promotes the redissolution of the support $\beta-\mathrm{Al}(\mathrm{OH})_{3}$, and due to the recalcination step leads to the formation of the phase $\gamma-\mathrm{Al}_{2} \mathrm{O}_{3}$ with high copper dispersion, according to the XRD results (Figure 1).

\section{Catalytic activity}

The different materials were applied in the gas-phase conversion of glycerol to acetol in order to observe the potential of these solids in catalytic processes. The conversion of glycerol and the acetol selectivity as a function of time for the two different methods is shown in Figure 5.

From Figure 5 is observed that the sample synthesized by wet impregnation method (3CuAl500) presents higher activity and selectivity compared to the $3 \mathrm{CuAl}$ catalysts prepared using only the polymeric precursor method. However, the Al sample is almost inactive and less selective for hydroxyacetone, suggesting that the active sites are copper species.

Therefore, the results confirm that the copper is the major active site, while the aluminium oxide plays a secondary role during the conversion of glycerol to acetol. Nevertheless, copper metal sites combined with an aluminium oxide site can play a major role in the activity, selectivity and stability of the samples. Thus, aluminium oxide acts mainly as structural and textural promoter, providing a larger surface area for solids containing copper oxide and aluminium oxide synthesized through wet impregnation route.

From the results presented, one can note that the structural, textural and morphological properties, and consequently the catalytic performance, depend on the way of catalyst preparation due to the fact 

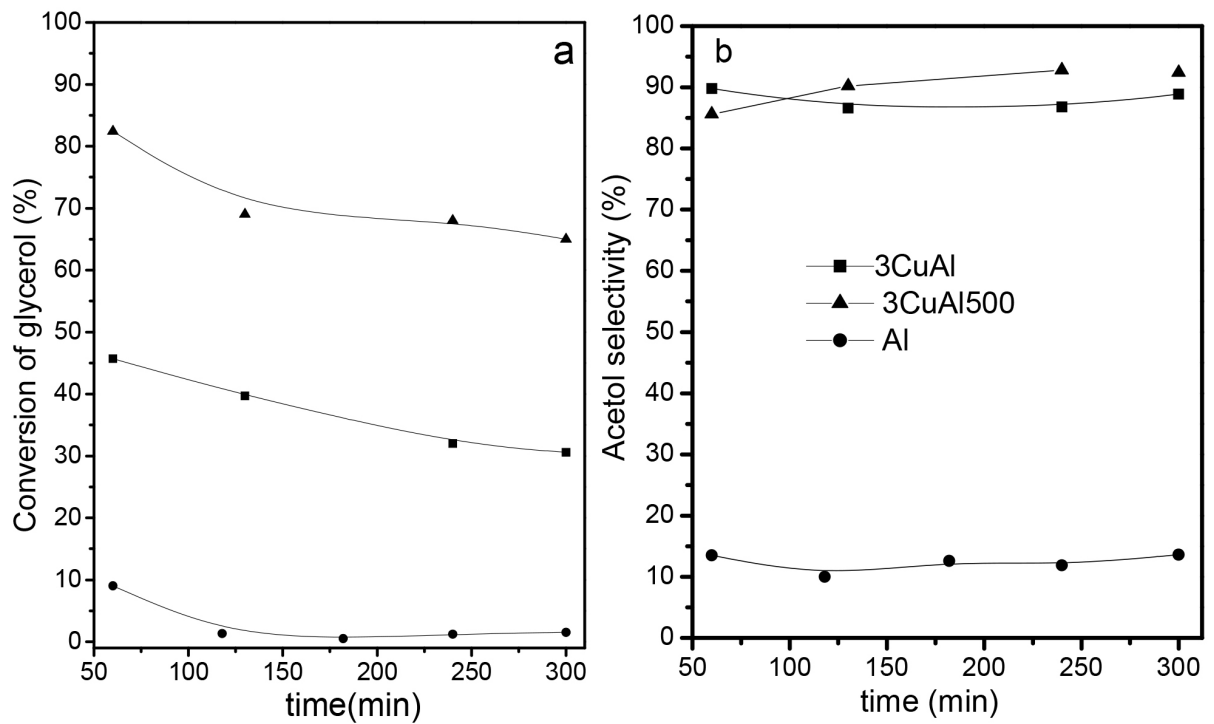

Figure 5. Catalytic performance of the samples: (a) conversion of glycerol, (b) acetol selectivity. Reaction conditions: $T_{\text {reaction }}=250{ }^{\circ} \mathrm{C}$; $\mathrm{T}_{\text {reduction }}=250{ }^{\circ} \mathrm{C}$; $\mathrm{m}_{\text {catalysts }}=200 \mathrm{mg}$

that the sample prepared by wet impregnation presented the gamma-alumina combined with highly dispersed copper oxide containing high surface area and, subsequently, better conversion and stability during the transformation of glycerol to acetol.

The other products selectivity (1,2-propanediol, propanoic acid and acetic acid) is presented in Table 3. For example, the sample $3 \mathrm{CuAl}$ presented the 1,2-propanediol, propanoic acid and acetic acid selectivity of $6.0,4.9$ and $0.1 \%$, respectively.

The selectivity results suggest that on the copper surface mainly occur the dehydrogenation reaction, which favor the acetol formation; while the dehydration is promoted by the aluminium oxide.

Table 3. Catalytic selectivity observed for others products

\begin{tabular}{cccc}
\hline \multirow{2}{*}{ Samples } & \multicolumn{3}{c}{ Selectivity $(\%)^{*}$} \\
\cline { 2 - 4 } & 1,2-propanediol & Propanoic acid & Acetic acid \\
\hline $\mathrm{Al}$ & 41.7 & 44.0 & 1.0 \\
$3 \mathrm{CuAl}$ & 6.0 & 4.9 & 0.1 \\
$3 \mathrm{CuAl} 500$ & 5.7 & 1.8 & 0.06 \\
\hline
\end{tabular}

The spent solids were analyzed by XRD (Figure 6) in order to obtain information concerning the reasons of the decrease in the conversion of glycerol to acetol (Figure 5). The average crystallite sizes were estimated using the Scherrer's formula (see Table 4).

The results presented in Figure 6 for the $3 \mathrm{CuAl}$ sample points to $\mathrm{Cu}^{2+}$ reduction during the reaction process. The diffraction pattern of the $3 \mathrm{CuAl}$ catalyst shows the cuprous oxide formation $\left(\mathrm{Cu}_{2} \mathrm{O}\right.$, JCPDS 00-003-0867) and metallic copper phase (Cu, JCPDS 00-001-1242).

However, the $3 \mathrm{CuA1500} \mathrm{X}$-ray diffractogram suggests that the structures of aluminium oxide $\left(\gamma-\mathrm{Al}_{2} \mathrm{O}_{3}\right.$, JCPDS 00-002-1414) with copper species highly dispersed was maintained after transformation of glycerol, since it was not observed the formation of crystalline phases of copper during the $4 \mathrm{~h}$ reaction period. XRD results of $3 \mathrm{CuAl} 500$ catalyst after the reaction (Figure 6) are very similar to the fresh catalyst (Figure 1), which may justify the best catalytic stability compared to the $3 \mathrm{CuAl}$ solid.

The average crystallite diameter using the Scherrer's formula for the spent catalysts is shown in Table 4 . The metallic $\mathrm{Cu}$ was observed in $3 \mathrm{CuAl}$ solid after reaction, with a large size of $30.8 \mathrm{~nm}$. On the other hand, the $\gamma-\mathrm{Al}_{2} \mathrm{O}_{3}$ phase for the sample $3 \mathrm{CuA} 500$ shows high

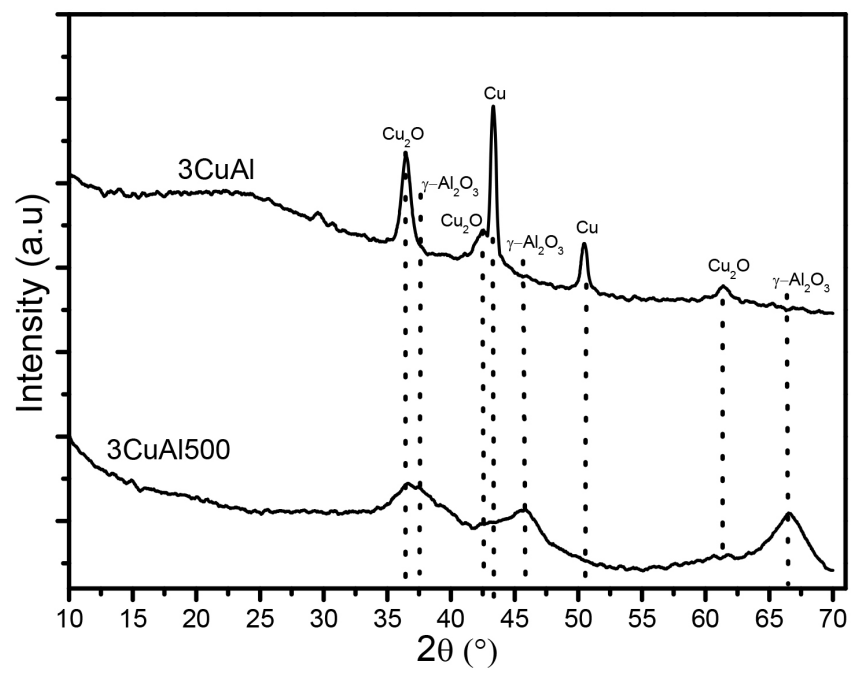

Figure 6. X-Ray diffraction patterns of the solids after the catalytic test

Table 4. Average crystallite sizes of the solids for the spent catalysts

\begin{tabular}{ccccc}
\hline \multirow{2}{*}{ Samples } & \multicolumn{5}{c}{ crystallite sizes $(\mathrm{nm})$} \\
\cline { 2 - 5 } & $\mathrm{Cu}_{2} \mathrm{O}$ & $\mathrm{Cu}$ & $\mathrm{CuO}$ & $\gamma-\mathrm{Al}_{2} \mathrm{O}_{3}$ \\
\hline $3 \mathrm{CuAl}$ & 15.1 & 30.8 & - & - \\
$3 \mathrm{CuA1500}$ & 6.4 & - & 4.8 & 5.9 \\
\hline
\end{tabular}

sintering-resistance ability due to the particle sizes after and before reaction being very similar, as can be observed in Tables 1 and 4. As discussed above, the $\mathrm{CuO}-\mathrm{Al}_{2} \mathrm{O}_{3}$ interaction effect in the samples synthesized by wet impregnation method may be responsible for the sintering-resistant behavior of the catalysts.

\section{CONCLUSION}

The wet impregnation method from the $\beta-\mathrm{Al}(\mathrm{OH})_{3}$ synthesized by polymeric precursor route was applied successfully for the preparation of $\gamma-\mathrm{Al}_{2} \mathrm{O}_{3}$ phase containing non-crystalline copper oxide with a high surface area. Copper oxide and alumina-based catalysts were tested in the reaction of glycerol to acetol. The XRD, $\mathrm{N}_{2}$ adsorption/desorption 
isotherms and SEM results showed that the way of catalyst preparation influences its structure, texture, morphology and, subsequently, the catalytic performance. The significant increase of surface area may be justified by redissolution of $\beta-\mathrm{Al}(\mathrm{OH})_{3}$ during impregnation of $\mathrm{Cu}^{2+}$ and recrystallization of bayerite to gamma-alumina during recalcination. The catalyst $\gamma-\mathrm{Al}_{2} \mathrm{O}_{3}$ with highly dispersed copper species achieved the highest catalytic activity compared to the sample containing crystalline copper oxide and bayerite. The presence of $\gamma-\mathrm{Al}_{2} \mathrm{O}_{3}$ interacting with copper oxide provides a lower sintering under reaction conditions.

\section{ACKNOWLEDGMENTS}

The authors acknowledge the "Universidade Federal do Ceará" (UFC) and Institut de recherches sur la catalyse et l'environnement (IRCE) in Lyon-France.

\section{REFERENCES}

1. Sato, S.; Akiyama, M.; Takahashi, R.; Hara, T.; Inui, K.; Yokota, M.; Appl. Catal. A2008, 347, 186.

2. Corma, A.; Iborra, S.; Velty, A.; ChemRev. 2007, 107, 2411.

3. Chiu, C. W.; Dasari, M. A.; Suppes, G. J.; Sutterlin, W. R.; AIChE J. 2006, 52, 3543 .

4. Lacasse, K.; Baumann, W.; Textile Chemicals Environmental Data and Facts, $1^{\text {st }}$ ed., Springer: Berlin, 2004.

5. Mohamad, M. H.; Awang, R.; Yunus, W.; Am. J. Appl. Sci. 2011, 8, 1135.

6. Jalbout, A. F.; Contreras, F. F.; Adamowicz, L.; InterScience 2008, 108, 279.

7. Apponi, A. J.; Hoy, J. J.; Halfen, D. T.; Ziurys, L. M.; Astrophys. J. 2006, 652, 1797.

8. Suprun, W.; Lutecki, M.; Haber, T.; Papp, H.; J. Mol. Catal. A: Chem. 2009, 309, 71

9. Li, K. T.; Wang, C.; Wang, H.; J. Taiwan Inst. Chem. Eng. 2015, 52, 79.

10. Mane, R. B.; Yamaguchi, A.; Malawadkar, A.; RSC Adv. 2013, 3, 16499.

11. Manfro, R. L.; Souza, M. V. M.; Catal. Lett. 2014, 144, 867.
12. Miranda, B. C.; Chimentãoa, R. J.; Sueiras, J. E.; Appl. Catal., B 2014, 147, 464.

13. Wojciechowska, M.; Zielinski, M.; Malczewska, A.; Przystajko, W.; Pietrowski, M.; Appl. Catal., A 2006, 298, 225.

14. Fortunato, G.; Oswald, H. R.; Reller, A.; J. Mater. Chem. 2001, 11, 905.

15. Chellam, U.; Xu, Z.; Zeng, H. C.; Chem. Mater. 2000, 12, 650

16. Cui, B.; Lin, H.; Li, J. B.; Li, X.; Yang, J.; Tao, J.; Adv. Funct. Mater. 2008, 18, 1440 .

17. Shchukin, D. G.; Yaremchenko, A. A.; Ferreira, M. G. S.; Kharton, V. V.; Chem. Mater. 2005, 17, 5124.

18. Ballarini, N.; Cavani, F.; Passeri, S.; Pesaresi, L.; Lee, A. F.; Wilson, K.; Appl. Catal., A2009, 366, 184.

19. Giannakas, A. E.; Ladavos, A. K.; Armatas, G. S.; Pomonis, P. J.; App. Surf. Sci. 2007, 253, 6969.

20. Woelk, H. J.; Hoffmann, B.; Mestl, G.; Schloegl, R.; J. Am. Ceram. Soc. 2002, 85, 1876 .

21. James, T.; Padmanabhan, M.; Warrier, K. G. K.; Sugunan, S.; Mat. Chem. Phys. 2007, 103, 248

22. Guo, J.; Lou, H.; Zhao, H.; Chai, D.; Zheng, X.; Appl. Catal., A. 2004, 273,75

23. Kwak, B. K.; Park, D. S.; Yun, Y. S.; Yi, J.; Catal. Commun. 2012, 24, 90.

24. Braga,T. P.; Essayem,N.; Valentini, A.; RSC Adv. 2015, 5, 93394.

25. Luo, M.; Fang, P.; He, M.; Xie, Y.; J. Mol. Catal. A: Chem. 2005, 239, 243.

26. Mai, H.; Mengfei, L.; Ping, F.; J. Rare Earths 2006, 24, 188.

27. Ozawa, M.; Toda, H.; Kato, O.; Suzuki, S.; Appl. Catal. B:Environ. 1996, $8,123$.

28. Peri, J. B.; J. Phys. Chem. 1965, 69, 220

29. Soled, S.; J. Catal. 1983, 81, 252.

30. Ozawa, M.; Suzuki, S.; Thomas, R. R.; App. Surf. Sci. 1997, 121, 441.

31. Carrier, X.; Marceau, E.; Lambert, J. F.; Che, M.; J. Colloid Interface Sci. 2007, 308, 429.

32. Trueba, M.; Trasatti, S. P.; Eur. J. Inorg. Chem. 2005, 17, 3393.

33. Maity, S.; James, O. O.; Chowdhury, B.; Auroux, A.; Curr Sci. 2014, 106,1538 . 